\title{
Changes of the Content of Heavy Metals and PAH's in Sewage Sludge Treated with Reed Bed Lagoons
}

\author{
Dariusz Boruszko' \\ 1 Faculty of Civil and Environmental Engineering, Bialystok University of Technology, 45A Wiejska St., 15-351 \\ Bialystok, Poland, e-mail: d.boruszko@pb.edu.pl
}

\begin{abstract}
ABSTARCT
In Poland, low-input methods such as composting, vermicomposting, reed beds, willow energy and solar driers are increasingly often being used in the processing of sewage sludge. The northeastern part of Poland has operated successfully for years using these methods. This paper presents the results of using low-cost methods of sludge treatment in the wastewater treatment plant located in Zambrow, Podlaskie Province. The results of sewage sludge studies on the PAHs and heavy metals content after treatment in a reed bed system are presented. Among the 16 examined PAHs, the lowest concentration was obtained for the dibenz (a,h)anthracene. Not a single sample exceeded a concentration of $100 \mu \mathrm{g} / \mathrm{kg} \mathrm{d.m}$. The highest concentration was exhibited by fluoranthene, benzo(g,h,i)perylene and indeno(1,2,3-c,d)pyrene. The concentration of these compounds exceeded $1000 \mu \mathrm{g} / \mathrm{kg} \mathrm{d} . \mathrm{m}$. The obtained results for the PAHs in sewage sludge from the reed lagoon at the treatment plant in Zambrow showed that the average content of PAHs studied was approximately $8300 \mu \mathrm{g} / \mathrm{kg} \mathrm{d} . \mathrm{m}$. The lowest concentration, below $1.3 \mathrm{mg} / \mathrm{kg}$ d.m. of the seven heavy metals examined was obtained for mercury $(\mathrm{Hg})$. On the other hand, the highest concentration, exceeding $1300 \mathrm{mg} / \mathrm{kg}$ d.m. was found in the case of zinc ( $\mathrm{Zn}$ ). The obtained results for the heavy metals in sewage sludge from the reed bed lagoons in Zambrow show that the average content of heavy metals studied is approximately $1620 \mathrm{mg} / \mathrm{kg} \mathrm{d.m}$. The results of the study demonstrate a high efficiency of the low-cost methods used in the Zambrów WWTP in terms of the quality of processed sludge. The sewage sludge from the lowest layer of the reed lagoon (13-14 years of dewatering and transformation) are characterized by the lowest PAHs and heavy metals content. The higher a sediment layer lies, i.e. the shorter the time of processing, the higher are the PAHs and content of heavy metals content. This indicates a great role of reeds in the accumulation of these compounds.
\end{abstract}

Keywords: polycyclic aromatic hydrocarbons, sludge treatment reed bed, speciation of heavy metals

\section{INTRODUCTION}

The low-input methods of processing sewage sludge are characteristic first of all by their simple design and technology as well as by their easy operation. These methods allow using only a limited number of process equipment resulting on low consumption of electrical energy. Utilisation of natural processes occurring in the environment allows maintaining low operation costs.

Reed lagoons are successfully used for the long-term stabilization and dehydration of sludge from waste water treatment. They are easy to construct and operate and consume small amounts of energy [Zwara \& Obarska-Pempkowiak 2000; Nielsen et al. 2012]. What is perhaps the most im- portant in STRB is that any kind of sewage sludge of organic character can be stabilized [Uggetti et al. 2010]. This technology has been applied with success for more than thirty years, among others in Denmark. The initial content of organic matter in the sediment between $50 \%$ and $65 \%$ and low load of the lagoon surface allow for drainage of sewage sludge to a degree no less as when using filter presses up to the value of $20-30 \% \mathrm{DM}$ [Nielsen 2003, 2011; Nielsen et al. 2012].

Reed lagoon is compulsorily equipped with a drainage system that allows ventilation of the processed sewage sludge and effluent discharge. The efficiency of dehydrating is also provided by gravity drainage and evaporation. In addition, the long process of sludge stabilization (7-15 years) 
remarkably reduces the organic matter content and causes the processes of sludge humification (Peruzzi et al. 2009). Many authors acknowledge that the sludge stabilized in STRB is similar in its chemical composition to the compost (high content of organic matter and nitrogen) [Kołecka \& Obarska-Pempkowiak 2008].

From the ecological point of view, the PAHs collection and transformation within individual ecosystems is more important. Since nearly $90 \%$ of the PAHs contained there come from soil, specific actions and means should be implemented to protect these ecosystems. Moreover, the studies conducted so far demonstrate differences in the degree and the speed of the PAH transformation in the soil, which proves their long life and the possibility of bioaccumulation in this environment. The PAH (and other organic compounds) also occur in plants, thus being a great concern, as the mechanism of absorbing the PAHs and other organic compounds is not fully understood. It is assumed that accumulation of harmful substances on the surface of leafs is possible during atmospheric precipitations or due to contamination with soil particles. Irrespective of that in many countries studies are conducted in order to determine the limit values for organic substance content in sewage sludge, composts and in potable water. In Europe, when sewage sludge is used in agriculture, the limits on the content of PAHs in naturally used municipal sewage sludge have been proposed [WD, 2000; WD, 2010]. Some of the EU countries have introduced internal limitation of PAHs contents in sewage sludge intended for use in agriculture [Aparicio et al. 2009; Gomez et al. 2002; Kapanen 2013; Langenkamp et al. 2001; Vacha et al. 2006]. In Germany, there are no binding regulations concerning the PAHs content in sludge, however, a designation of $9 \mathrm{PAH}$ is recommended; the sum of which should not exceed $6000 \mu \mathrm{g} / \mathrm{kg}$ d.m. In the proposed amendment to the Sediment Directive, the sum of 11 hydrocarbons should not exceed $6000 \mu \mathrm{g} / \mathrm{kg}$ d.m.

The Polish legislation does not provide any regulations on the maximum PAHs content in sewage sludge designed for use in the agriculture. There is no uniform procedure of analytic analysis of PAHs in sludge either. Determination of micro-contaminations in the sewage sludge is one of the most complicated analytical tasks connected with the heterogeneity of these materials and with differentiated PAH concentrations [Smolik 2005].

Although in Poland the PAHs content in the sediments used in agriculture is not subject to norms, these substances are taken into account in the draft of alterations/amendments to the UE Directive $75 / 442 / E W G$ according to which a permissible summary concentration of 11 aromatic compounds (acenaphtene, phenatrene, fluorene, fluorantene, pyrene, benzo(k)fluorantene, benzo(a)pyrene, benzo(ghi)perylene, indeno(1,2,3-cd)pyrene) should be $6 \mathrm{mg} \cdot \mathrm{kg}-1$ (converted to dry mass).

The content of heavy metals in the stabilized sewage sludge is often crucial for the possibility of their use in agriculture. Their excessive content in the sewage sludge may be toxic and dangerous to the environment. The knowledge on their overall content, but also their fractional distribution is highly important. The spread of BCR method enabling to determine the heavy metals present in sewage sludge in 4 fractions was of great importance for science: ion exchange and carbonate fraction (I - the most mobile), hydroxide fraction (bound with oxide and hydroxide iron and magnesium) (II), organic fraction (III), residua fraction (IV - the most stable) [Boruszko 2013a; Peruzzi et al. 2011; Kolecka \& Obarska-Pempkowiak 2008].

This paper presents selected examples of experience and the study of one of the first wastewater treatment plants in the Podlaskie Province in Zambrów run by the Zambrowskie Ciepłownictwo i Wodociągi sp. z o.o. (District Heating and Waterworks Zambrów Ltd), which has successfully treated sewage sludge by lowcost methods for a dozen or so years.

During the research, the following values were determined: dry matter and organic matter concentration as well as concentration of nitrogen, phosphorus, 16 polycyclic aromatic hydrocarbons PAHs, total and selected heavy metals: $\mathrm{Cd}, \mathrm{Cr}, \mathrm{Cu}, \mathrm{Ni}, \mathrm{Pb}, \mathrm{Zn}$.

\section{METHODS}

\section{Analyzed systems}

In the municipal wastewater treatment plant of Zambrów, approximately 1 ton DM of raw sewage sludge is generated per day. The sludge management is based on sludge lagoons, reed beds and earthworm fields. Outside of the win- 
ter season, $70 \%$ of the sludge is carried away directly to a reed bed with an area 3 times $3500 \mathrm{~m}^{2}$. In winter, the sludge is directed onto sludge lagoons provided with a vertical drainage, ensuring a high efficiency of the sludge dewatering while filling the lagoon. In the wastewater treatment plant there are 2 sludge lagoons with a capacity of $2500 \mathrm{~m}^{3}$ each. Approximately $80-90 \%$ of the sludge collected on sludge lagoons is pumped in summer time onto earthworm fields with an area of about 1 ha. The remaining sludge is utilised in the agriculture, for reclamation in autumn (after harvest). This solution allows shortening the time of the sludge removal from the wastewater treatment plant down to two weeks, i.e. during emptying the sludge lagoon and after removing the sludge from earthworm fields during a period when this product is needed.

Sedimentary lagoons - reeds bed stayed partly in the excavation and partly in the embankment. The height from the top of the embankment is taking $3.2 \mathrm{~m}$ flat out into the bottom of the lagoon. The primer base of lagoons is built of clenched clay. Sequences were arranged in the bottom drainage $(\phi 100)$ in the filter ballast taken to the pumping station located in the lagoon. The channel is being depumped into the production line to sewers reaching the sewage treatment plant, i.e. a local pumping station. The supplying of sludge was solved by laying a crown escarpments of pipelines from PVC pipes of built in three-way adapters. In the upper layer of the filter ballast in the first year of the use they effected planting the reed in the quantity of 8 cuttings to the square metre. In the winter period, the lagoons are not being fed with sludge. The ground part of the reed was not removed for the entire operating period. In early spring, wither rushes of the reed constitute the additional organic substances. Long-term storing of reed "transfers" dead ground parts of plants every year, creating similar conditions to of the ones in a compost heap.

\section{Sampling strategy}

The samples were collected at 4 points, evenly spaced along the symmetry axes for each basin. The samples of the sludge from the same layers were mixed and their quality was determined.

\section{The equipment}

From 2012-2014, the sludge samples were taken from the middle part of the oldest reed bed (still in service) in the 3-meter profile of the sediment fill. Sampling was performed using a special probe to enable the extraction of sewage sludge from the full depth of the lagoon. The samples were averaged and sludge samples from each 0.5 $\mathrm{m}$ section were tested. In 2013, the service of the oldest lagoon was finished after 14 years.

The studies reflect the following STBR cycles:

- end of 2012 - after last 14th year of STBR supply with sewage sludge at full load,

- end of 2013 - after transitional year at STBR supply with sewage sludge at minimum load,

- end of 2014 - year after STBR closing.

\section{Analitycal procedure}

The analysis of the obtained material included, among others, carrying out the following examinations: heavy metal content, fertilizing values, liquefication, dry mass, and polycyclic aromatic hydrocarbons (PAHs). The examinations were carried out in the Department of Technology in Engineering and Environmental Protection laboratory, according to the valid norms.

Dry matter and organic matter were determined by using standard methods [APHA 2005].

Kjeldahl nitrogen $(\mathrm{N})$, the sum of organic and ammonia nitrogen, was determined in the analyzed sludge. The sludge sample was dried and homogenized. It was then alkalized using a 35\% solution of $\mathrm{NaOH}$ and mineralized in the presence of the catalyst $\mathrm{CuSO}_{4}+\mathrm{K}_{2} \mathrm{SO}_{4}$ using ammonium destilation [APHA 2005]. Determination of ammonia nitrogen was carried out using the distillation method.

For determining the phosphorus concentration, the sample was dried, homogenized and then mineralized using a mixture of the concentrated acids $\mathrm{HCLO}_{4}$ and $\mathrm{HNO}_{3}$. In the obtained solution, the $\mathrm{PO}_{4}^{-}$ions were determined calorimetrically in the reaction with ammonia molybdate in the presence of glycerin with dissolved $\mathrm{SnCl}_{2}$ [APHA 2005].

The study of polycyclic aromatic hydrocarbons (PAHs) contents in sewage sludge was carried out using gas chromatography coupled with mass spectrometry detection. In purified and concentrated extracts from sewage sludge, 16 PAHs were identified (according to US EPA): naphthalene (NAPH), acenaphthylene (ACY), acenaphthene (ACE), fluorene (FLU), phenanthrene (PHE), anthracene (ANT), fluoranthene 
(FLA), pyrene (PYR), benzo[a]anthracene (B[a] ANT), chrysene (CHR), benzo[b]fluoranthene (B[b]FLA), benzo[k]fluoranthene (B[k]FLA), benzo[a]pyrene (B[a]PYR), dibenzo[a,h]anthracene $(\mathrm{D}[\mathrm{a}, \mathrm{h}]$ ANT), indeno[1,2,3-c,d]pyrene $(\operatorname{Ind}[1,2,3-\mathrm{c}, \mathrm{d}] \mathrm{P})$, benzo[g,h,i]perylene $(\mathrm{B}[\mathrm{g}, \mathrm{h}, \mathrm{i}]$ PER), as well as their sum [APHA 2005].

\section{Extraction procedure}

From $10 \mathrm{~g}$ to $20 \mathrm{~g}$ of sludge sample with a field moisture content was weighed and placed in a conical flask with a capacity of $200 \mathrm{ml}$. Then, $50 \mathrm{ml}$ of acetone was added; the flask was sealed and subjected to extraction on a shaker for 1 hour. Petroleum ether wit the volume of $50 \mathrm{ml}$ was added and agitated again for 1 hour. The supernatant was decanted and shaken with another $50 \mathrm{ml}$ petroleum ether portion. The supernatant liquid was subsequently decanted. The extracts were combined and acetone and other polar compounds were removed by shaking twice with $400 \mathrm{ml}$ of water. The water was discarded. The organic layer was dried over anhydrous sodium sulfate (VI) and then filtered through a filter. The dried extract was transferred to a concentrating device; $100 \mathrm{ml}$ of isooctane was added as a stabilizer and concentrated to the volume of about $2 \mathrm{ml}$. The resulting solution was analyzed by means of GC-MS.

\section{Calibration}

Five solutions containing the calibration standard mixture and the test sample matrix were analyzed. The calibration function was calculated by linear regression of the corrected peak areas. The current sensitivity of the method was estimated from the calculated regression function. The calibration was performed on the measurement day. Additionally, determination of a certified reference material was carried out in order to investigate the recoveries of PAHs. The values of PAHs recoveries ranged between $80 \%$ and $120 \%$, which is permissible for chromatographic methods [Oleszczuk \& Baran 2004].

The PAHS extraction was conducted with the use of acetone and petroleum ether. Two extraction methods are described in International Norm: two-phased and one-phased extraction. Twophased extraction was used in the research.

The sludge samples were treated with mineralization in $\mathrm{HACH}$ mineralizator with the use of sylphuric acid and hydrogen peroxide in a mixture of nitric and hydrochloric acid in the ratio of $1: 3$. For further analysis, the mineralizators were filtered through MN $616 \mathrm{G}$ paper filter.

Determination of the cadmium, nickel and total chromium content was done in the samples of mineralizators with the use of Perkin-Elmer 4100 ZL atomic absorption spectrometr with transversely heated graphite cuvette and Zeemaneffect background correction.

Determination of the mercury content was performed in the samples of mineralizators by means of cold steam technique with the use of Perkin-Elmer 4100 ZL atomic absorption spectrometr equipped with FIAS-200 add-on device.

Determination of the zinc, lead and copper content was carried out in the samples of mineralizators using Varian SpectrAA 20 Plus atomic absorption spectrometr by means of flame atomization.

The determination of individual fractions of heavy matals was completed using the sequential extraction method according to The Community Bureau of Reference (now Standarts measurement and testing Programme) - BCR [Scancar et al. 2000; Kazi et al. 2005]. Four solutions were used in the test: 0.11 molar $\mathrm{CH}_{3} \mathrm{COOH}$ (Fraction I), 0.5 molar $\mathrm{NH}_{2} \mathrm{OH} \cdot \mathrm{HCL}$; $\mathrm{pH}$ 1,5 (Fraction II), 1 molar $\mathrm{NH}_{3} \mathrm{COONH}_{3}$; pH 2 (Fraction III) and mixture $\mathrm{H}_{2} \mathrm{O}_{2}$ and $\mathrm{HNO}_{3}$ (Fraction IV), respectively. Using these extractions, the following four fractions of metals were separated: ion exchange and carbonate fraction (I - the most mobile), hydroxide fraction (Bound with oxide and hydroxide iron and magnesium) (II), organic fraction (III), residual fraction (IV - the most stable).

\section{Data analysis}

Determinations of the test samples were performed in triplicate. The mathematical-statistical calculations presented in the paper were made using common computer software and spreadsheets. In order to study the relationship between the quantitative parameters and to describe the strength of the correlation in the case of a small number of observations, the Spearman's rank correlation coefficient was applied [Sobczyk, 2002]. In order to verify whether there was a statistically significant change, ANOVA rank Kruskala-Wallisa and Friedman were used for each pair of observations [Siegel 1956]. 


\section{RESULTS AND DISCUSION}

A change in the basic parameters of stabilized sewage sludge in reed lagoons is shown in Figure 1. The sludge is stabilized and dehydrated. The degree of sludge dehydration is low and ranges from $2.9 \%$ in 2012 to $3.1 \%$ in 2014 . The lowest dry matter content was recorded in the top layer of a vertical profile $-12.6 \%$. The highest content of dry matter characterized sludge that was deposited on the reed lagoon for the longest period of time (the lowest layer in vertical profile) reached $14.5 \%$. In the middle section of the vertical profile of sludge at a depth of 1.5-2.0 m, a remarkable reduction in the dry matter content was observed: to $10.4 \%$ in 2012 and $13.2 \%$ in 2014. The dry matter content in STRB at different depths of vertical profile is a measure of dehydration. The degree of dehydration is on the one hand dependent on the degree of water evaporation from the lagoon surface and on the other hand on the gravitational concentration and uptake by reed roots [Kolecka \& Obarska-Pempkowiak 2008]. Definitely higher dry matter contents above $29 \%$ in the sludge stabilized in STRB were achieved in the studies by Matamoros et al. [2012].

The content of organic matter oscillated within a wider range. The lowest organic matter content of $49.0 \%$ DM was recorded in the deepest layer of sludge in 2014 , i.e. one year after closing the reed lagoon. The highest organic matter values were observed in the highest sludge layer (sludge that was drained and stabilized for the shortest time); this value ranged from 58.1\% DM to $62.2 \% \mathrm{DM}$. The organic matter accumulated in the sludge over the years becomes biodegraded and stabilized, leading to a reduction in dry matter content. Similar results of the organic matter reduction by $10-12 \%$ were obtained by Nielsen [2005] and in the studies conducted in Poland in Darżlubie [Zwara \& Obarska Pempkowiak 2000].

The average nitrogen content in the sludge stabilized over three years ranged from 3.5\% DM to $3.8 \% \mathrm{DM}$. The highest nitrogen concentration characterized the top layers of the sludge, ranging from 3.7\% DM to $4.1 \% \mathrm{DM}$, while the lowest nitrogen contents were found in the sludge from the deepest layers, ranging from $3.3 \% \mathrm{DM}$ to $3.4 \%$ DM. There was a constant, yet slight, nitrogen loss during its stabilization in the reed lagoon. It was described in earlier studies [Boruszko 2015; Peruzzi et al. 2009]. A decrease in the nitrogen content in STRB-stabilized sludge is a result of the element uptake by plants and microbial conversions occurring around the root system (nitrification and denitrification).

Mean phosphorus content in the stabilized sludge was similar, ranging in 2012-2014 between $2.7 \% \mathrm{DM}$ and $2.8 \% \mathrm{DM}$. The deepest sludge layers (in vertical profile) were characterized by the highest phosphorus content (samples from $2.5-3.0 \mathrm{~m}$ depth) at average value of $3.2 \%$ DM. The lowest phosphorus contents were recorded in sludge samples from the shallowest layer $0.0-0.5 \mathrm{~m}$ (sludge that was stabilized for the shortest time); value at this profile ranged from $1.9 \%$ DM in 2014 to $2.3 \%$ DM in 2012. Studies have confirmed that very long stabilization and decomposition of organic matter can retain phosphorus in the sludge.

The changes in the contents of each of the analyzed 16 PAHs in six layers of the vertical profile of STRB dehydrated and stabilized sludge conducted in 2012-2014 are presented in Table 1 as average values with standard deviation.
1.1

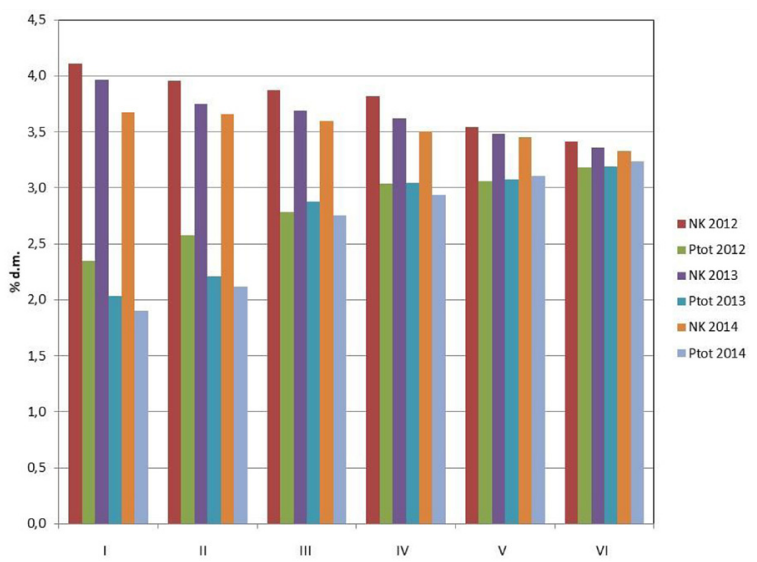

1.2

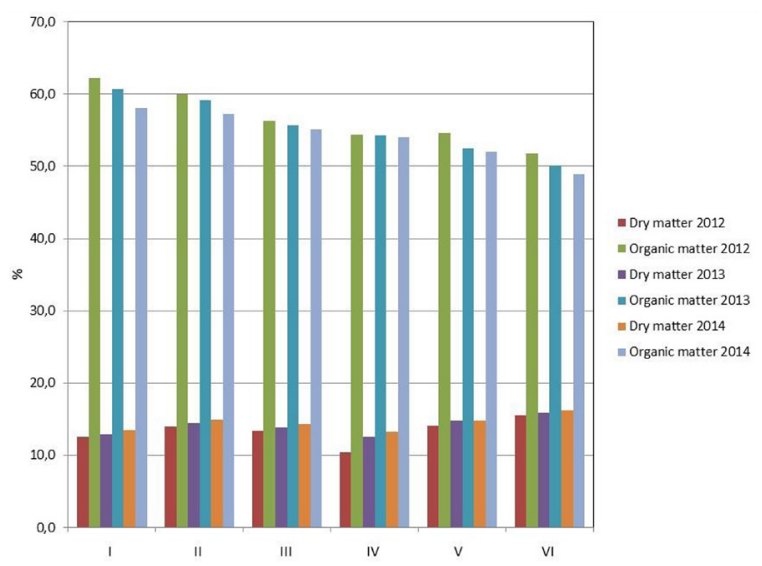

Figure 1. Physicochemical parameters in sludge in reed bed system in 2012, 2013 and 2014 year 
Table 1. Quantitative PAHs changes ( $\mu \mathrm{g} / \mathrm{kg} \mathrm{d.m)} \mathrm{in} \mathrm{sludge} \mathrm{stabilized} \mathrm{in} \mathrm{reed} \mathrm{bed} \mathrm{system} \mathrm{in} \mathrm{2012,} 2013$ and 2014 year

\begin{tabular}{|c|c|c|c|c|c|c|c|}
\hline Year & 1 & II & III & IV & $\mathrm{V}$ & $\mathrm{VI}$ & Average \\
\hline \multicolumn{8}{|c|}{ Naphthalene } \\
\hline 2012 & $278.0 \pm 3.6$ & $276.3 \pm 5.5$ & $266.3 \pm 5.5$ & $265.0 \pm 5.6$ & $264.7 \pm 6.5$ & $265.0 \pm 5.0$ & $269.2 \pm 6.2$ \\
\hline 2013 & $234.7 \pm 10.5$ & $243.0 \pm 10.8$ & $220.3 \pm 6.0$ & $253.7 \pm 2.5$ & $260.3 \pm 5.5$ & $258.3 \pm 7.5$ & $245.1 \pm 15.5$ \\
\hline 2014 & $194.3 \pm 5.0$ & $235.7 \pm 7.0$ & $242.3 \pm 7.0$ & $255.0 \pm 5.6$ & $239.0 \pm 6.6$ & $248.0 \pm 8.0$ & $235.7 \pm 21.4$ \\
\hline \multicolumn{8}{|c|}{ Acenaphtylene } \\
\hline 2012 & $331.7 \pm 8.7$ & $320.3 \pm 7.6$ & $308.7 \pm 6.1$ & $305.7 \pm 5.0$ & $277.3 \pm 6.5$ & $254.7 \pm 5.1$ & $299.7 \pm 28.6$ \\
\hline 2013 & $315.0 \pm 6.0$ & $304.0 \pm 6.0$ & $296.3 \pm 7.8$ & $286.7 \pm 7.1$ & $260.7 \pm 3.5$ & $234.3 \pm 5.0$ & $282.8 \pm 30.1$ \\
\hline 2014 & $302.0 \pm 7.5$ & $314.0 \pm 6.0$ & $277.3 \pm 7.0$ & $278.7 \pm 1.5$ & $263.3 \pm 7.5$ & $235.7 \pm 5.0$ & $278.5 \pm 27.9$ \\
\hline \multicolumn{8}{|c|}{ Acenaphtene } \\
\hline 2012 & $164.3 \pm 3.1$ & $177.0 \pm 6.6$ & $251.7 \pm 7.6$ & $299.3 \pm 6.4$ & $284.7 \pm 2.1$ & $204.3 \pm 3.5$ & $230.2 \pm 56.6$ \\
\hline 2013 & $176.7 \pm 5.5$ & $181.0 \pm 3.6$ & $268.3 \pm 6.1$ & $332.0 \pm 6.0$ & $302.7 \pm 6.5$ & $224.3 \pm 2.1$ & $247.5 \pm 64.2$ \\
\hline 2014 & $164.3 \pm 6.8$ & $192.7 \pm 6.0$ & $234.3 \pm 4.5$ & $355.3 \pm 7.0$ & $366.3 \pm 6.0$ & $270.3 \pm 8.0$ & $263.9 \pm 83.4$ \\
\hline \multicolumn{8}{|c|}{ Fluorene } \\
\hline 2012 & $78.7 \pm 2.1$ & $79.0 \pm 2.0$ & $84.0 \pm 1.7$ & $92.3 \pm 1.5$ & $87.3 \pm 2.1$ & $63.3 \pm 2.5$ & $80.8 \pm 10.0$ \\
\hline 2013 & $84.7 \pm 1.5$ & $84.0 \pm 2.0$ & $97.0 \pm 2.0$ & $122.3 \pm 7.0$ & $104.0 \pm 4.6$ & $81.0 \pm 4.0$ & $95.5 \pm 15.8$ \\
\hline 2014 & $76.7 \pm 1.5$ & $81.7 \pm 1.5$ & $97.3 \pm 1.5$ & $140.7 \pm 0.6$ & $131.7 \pm 1.5$ & $88.7 \pm 1.5$ & $102.8 \pm 26.9$ \\
\hline \multicolumn{8}{|c|}{ Phenanthene } \\
\hline 2012 & $763.3 \pm 10.6$ & $781.7 \pm 10.6$ & $852.3 \pm 7.5$ & $990.0 \pm 8.0$ & $893.0 \pm 7.0$ & $814.7 \pm 6.5$ & $849.2 \pm 83.5$ \\
\hline 2013 & $646.7 \pm 12.6$ & $672.3 \pm 2.1$ & $701.7 \pm 11.7$ & $830.7 \pm 10.5$ & $821.0 \pm 10.5$ & $708.3 \pm 8.5$ & $730.1 \pm 77.4$ \\
\hline 2014 & $552.7 \pm 5.0$ & $566.7 \pm 5.5$ & $676.7 \pm 6.1$ & $788.3 \pm 8.0$ & $776.0 \pm 6.0$ & $739.3 \pm 7.0$ & $683.3 \pm 103.4$ \\
\hline \multicolumn{8}{|c|}{ Antracene } \\
\hline 2012 & $203.7 \pm 3.1$ & $198.3 \pm 6.0$ & $133.3 \pm 6.1$ & $98.3 \pm 0.6$ & $79.0 \pm 2.0$ & $82.3 \pm 2.1$ & $132.5 \pm 56.5$ \\
\hline 2013 & $177.3 \pm 8.0$ & $168.7 \pm 8.5$ & $155.0 \pm 7.5$ & $122.0 \pm 6.6$ & $90.3 \pm 2.5$ & $71.7 \pm 4.5$ & $130.8 \pm 43.4$ \\
\hline 2014 & $172.3 \pm 6.5$ & $155.3 \pm 6.0$ & $144.7 \pm 5.5$ & $109.7 \pm 4.5$ & $102.7 \pm 2.5$ & $83.7 \pm 2.5$ & $128.1 \pm 34.4$ \\
\hline \multicolumn{8}{|c|}{ Fluoranthene } \\
\hline 2012 & $1643.3 \pm 30.3$ & $1541.7 \pm 18.5$ & $1494.3 \pm 26.5$ & $1457.0 \pm 18.7$ & $912.3 \pm 7.5$ & $818.3 \pm 12.2$ & $1311.2 \pm 352.2$ \\
\hline 2013 & $1551.3 \pm 13.7$ & $1409.0 \pm 20.5$ & $1386.0 \pm 11.0$ & $1321.7 \pm 20.0$ & $1026.3 \pm 15.0$ & $943.0 \pm 19.1$ & $1272.9 \pm 237.0$ \\
\hline 2014 & $1421.3 \pm 16.5$ & $1342.0 \pm 19.3$ & $1316.3 \pm 15.0$ & $1199.3 \pm 8.6$ & $1105.0 \pm 6.0$ & $933.7 \pm 7.4$ & $1219.6 \pm 179.1$ \\
\hline \multicolumn{8}{|c|}{ Pyrene } \\
\hline 2012 & $731.3 \pm 8.0$ & $842.0 \pm 7.2$ & $881.0 \pm 11.5$ & $875.3 \pm 8.3$ & $908.3 \pm 10.2$ & $845.7 \pm 11.0$ & $847.3 \pm 61.8$ \\
\hline 2013 & $656.3 \pm 15.5$ & $702.7 \pm 10.7$ & $872.3 \pm 12.7$ & $884.0 \pm 15.5$ & $914.3 \pm 13.0$ & $863.0 \pm 11.0$ & $815.4 \pm 107.7$ \\
\hline 2014 & $744.7 \pm 8.5$ & $775.0 \pm 8.2$ & $835.7 \pm 8.6$ & $888.7 \pm 8.1$ & $940.3 \pm 9.5$ & $908.0 \pm 7.0$ & $848.7 \pm 77.4$ \\
\hline \multicolumn{8}{|c|}{ Benz[a]antracene } \\
\hline 2012 & $241.7 \pm 11.4$ & $265.3 \pm 5.0$ & $260.0 \pm 5.6$ & $301.3 \pm 3.1$ & $291.3 \pm 6.1$ & $267.3 \pm 8.5$ & $271.2 \pm 21.7$ \\
\hline 2013 & $232.0 \pm 11.1$ & $256.3 \pm 11.5$ & $244.0 \pm 15.5$ & $296.0 \pm 10.5$ & $303.7 \pm 14.0$ & $277.0 \pm 12.1$ & $268.2 \pm 28.8$ \\
\hline 2014 & $203.7 \pm 4.5$ & $219.7 \pm 10.1$ & $233.3 \pm 5.0$ & $309.0 \pm 63.3$ & $287.7 \pm 9.5$ & $282.3 \pm 6.1$ & $255.9 \pm 42.6$ \\
\hline \multicolumn{8}{|c|}{ Chrysene } \\
\hline 2012 & $421.7 \pm 11.0$ & $455.7 \pm 10.7$ & $435.3 \pm 8.5$ & $465.7 \pm 10.0$ & $486.0 \pm 4.6$ & $489.7 \pm 9.5$ & $459.0 \pm 27.1$ \\
\hline 2013 & $403.0 \pm 9.5$ & $454.0 \pm 14.1$ & $463.3 \pm 13.1$ & $477.3 \pm 12.7$ & $495.3 \pm 13.5$ & $485.0 \pm 13.5$ & $463.0 \pm 32.9$ \\
\hline 2014 & $431.7 \pm 10.5$ & $477.3 \pm 12.0$ & $488.0 \pm 11.5$ & $525.7 \pm 16.2$ & $525.7 \pm 6.0$ & $516.0 \pm 8.0$ & $494.1 \pm 36.6$ \\
\hline \multicolumn{8}{|c|}{ Benzo (b) fluoranthene } \\
\hline 2012 & $822.0 \pm 12.5$ & $707.0 \pm 9.5$ & $812.0 \pm 9.0$ & $886.3 \pm 9.3$ & $311.3 \pm 9.0$ & $409.7 \pm 10.3$ & $658.1 \pm 239.6$ \\
\hline 2013 & $853.7 \pm 12.5$ & $801.3 \pm 11.6$ & $842.7 \pm 15.0$ & $854.0 \pm 14.1$ & $421.3 \pm 17.0$ & $447.3 \pm 12.5$ & $703.4 \pm 209.5$ \\
\hline 2014 & $787.7 \pm 11.1$ & $811.3 \pm 9.0$ & $775.3 \pm 5.5$ & $794.0 \pm 7.2$ & $530.3 \pm 8.0$ & $502.7 \pm 6.5$ & $700.2 \pm 143.1$ \\
\hline \multicolumn{8}{|c|}{ Benzo (k) fluoranthene } \\
\hline 2012 & $567.7 \pm 8.6$ & $501.3 \pm 11.0$ & $537.3 \pm 8.0$ & $578.0 \pm 9.5$ & $432.7 \pm 11.1$ & $331.0 \pm 9.8$ & $491.3 \pm 94.6$ \\
\hline 2013 & $622.3 \pm 16.6$ & $608.0 \pm 11.1$ & $564.7 \pm 12.5$ & $558.0 \pm 9.0$ & $467.7 \pm 12.0$ & $384.3 \pm 8.0$ & $534.2 \pm 91.2$ \\
\hline 2014 & $602.7 \pm 7.5$ & $577.0 \pm 6.6$ & $555.0 \pm 7.0$ & $519.3 \pm 10.6$ & $405.3 \pm 6.1$ & $366.7 \pm 6.5$ & $504.3 \pm 96.4$ \\
\hline \multicolumn{8}{|c|}{ Benzo (a) pyrene } \\
\hline 2012 & $719.7 \pm 12.3$ & $719.7 \pm 10.6$ & $822.7 \pm 9.5$ & $847.3 \pm 10.0$ & $653.7 \pm 11.5$ & $473.0 \pm 16.5$ & $706.0 \pm 134.9$ \\
\hline 2013 & $747.3 \pm 8.5$ & $754.0 \pm 12.1$ & $878.0 \pm 10.1$ & $887.3 \pm 10.6$ & $619.7 \pm 16.3$ & $520.7 \pm 14.6$ & $734.5 \pm 143.8$ \\
\hline 2014 & $561.7 \pm 6.7$ & $686.7 \pm 6.5$ & $820.7 \pm 11.1$ & $831.3 \pm 9.3$ & $693.7 \pm 11.5$ & $555.0 \pm 13.1$ & $691.5 \pm 119.8$ \\
\hline
\end{tabular}


Table 1. cont.

\begin{tabular}{|c|c|c|c|c|c|c|c|}
\hline \multicolumn{7}{|c|}{ Indeno(1.2.3-cd) phyrene } \\
\hline 2012 & $878.0 \pm 9.2$ & $824.0 \pm 11.0$ & $1128.7 \pm 19.6$ & $1298.7 \pm 21.5$ & $827.7 \pm 12.0$ & $614.7 \pm 9.7$ & $928.6 \pm 244.6$ \\
\hline 2013 & $655.3 \pm 12.0$ & $734.3 \pm 13.5$ & $1025.0 \pm 24.1$ & $1016.3 \pm 12.6$ & $933.7 \pm 15.8$ & $712.7 \pm 11.0$ & $846.2 \pm 164.5$ \\
\hline 2014 & $607.7 \pm 10.8$ & $878.0 \pm 9.2$ & $990.7 \pm 8.7$ & $1011.0 \pm 9.5$ & $869.3 \pm 5.5$ & $764.0 \pm 9.2$ & $853.4 \pm 150.3$ \\
\hline \multicolumn{7}{|c|}{ Dibenzo (a. h) anthracene } \\
\hline 2012 & $41.7 \pm 0.6$ & $37.3 \pm 1.5$ & $52.7 \pm 2.5$ & $60.3 \pm 0.6$ & $28.7 \pm 0.6$ & $25.0 \pm 1.0$ & $40.9 \pm 13.7$ \\
\hline 2013 & $12.0 \pm 1.0$ & $47.0 \pm 3.0$ & $54.3 \pm 3.1$ & $64.0 \pm 3.0$ & $31.7 \pm 0.6$ & $31.7 \pm 1.5$ & $40.1 \pm 18.7$ \\
\hline 2014 & $11.0 \pm 1.0$ & $37.3 \pm 2.5$ & $61.7 \pm 2.1$ & $56.7 \pm 2.1$ & $27.7 \pm 1.5$ & $29.3 \pm 0.6$ & $37.3 \pm 19.1$ \\
\hline \multicolumn{7}{|c|}{ Benzo (g. h. i) perylene } \\
\hline 2012 & $869.3 \pm 15.9$ & $889.7 \pm 8.7$ & $1213.3 \pm 16.5$ & $1314.0 \pm 21.9$ & $934.3 \pm 9.5$ & $864.7 \pm 11.0$ & $1014.2 \pm 197.4$ \\
\hline 2013 & $577.0 \pm 6.6$ & $658.0 \pm 9.5$ & $1114.0 \pm 16.4$ & $1184.7 \pm 5.5$ & $1005.0 \pm 6.0$ & $779.3 \pm 12.2$ & $886.3 \pm 250.7$ \\
\hline 2014 & $595.3 \pm 47.5$ & $621.3 \pm 11.6$ & $984.0 \pm 6.1$ & $995.0 \pm 4.0$ & $946.3 \pm 7.1$ & $631.7 \pm 9.7$ & $795.6 \pm 197.6$ \\
\hline \multicolumn{7}{|c|}{ Total PAHs } \\
\hline 2012 & $8756.0 \pm 43.6$ & $8616.3 \pm 26.1$ & $9533.7 \pm 50.7$ & $10134.7 \pm 14.0$ & $7672.3 \pm 14.3$ & $6823.3 \pm 49.9$ & $8589.4 \pm 1205.7$ \\
\hline 2013 & $7945.3 \pm 17.6$ & $8077.7 \pm 104.0$ & $9183.0 \pm 30.3$ & $9490.7 \pm 29.5$ & $8057.7 \pm 35.6$ & $7022.0 \pm 76.3$ & $8296.1 \pm 901.6$ \\
\hline 2014 & $7429.7 \pm 42.5$ & $7971.7 \pm 42.8$ & $8733.3 \pm 27.0$ & $9057.7 \pm 62.9$ & $8210.3 \pm 19.0$ & $7155.0 \pm 38.2$ & $8092.9 \pm 733.3$ \\
\hline
\end{tabular}

\pm- standard deviation

(I - depth 0.0-0.5 m, II - depth 0.5-1.0 m, III - depth 1.0-1.5 m, IV - depth 1.5-2.0 m, V - depth 2.0-2.5 m, VI - depth $2.5-3.0 \mathrm{~m})$

The mean content of 16 PAHs sum in the sewage sludge was from $8092.9 \mu \mathrm{g} / \mathrm{kg}$ DM in 2014 to $8589.4 \mu \mathrm{g} / \mathrm{kg} \mathrm{DM}$ in 2012. The lowest sum of 16 PAHs was recorded for the deepest sludge layer in the vertical profile (at a depth of 2.5-3.0 m) in 2012, which amounted to $6823.3 \mu \mathrm{g} / \mathrm{kg} \mathrm{DM}$. The highest level of 16 PAHs sum was found in the middle sludge layer of the vertical profile at a depth of 1.5-2.0 $\mathrm{m}$ in 2012, which was 10134.7 $\mu \mathrm{g} / \mathrm{kg}$ DM. Among the 16 analyzed PAHs, the highest average content in the sewage sludge in STRB characterized fluoranthene, the amount of which equalled $1311.2 \mu \mathrm{g} / \mathrm{kg} \mathrm{DM}$, as well as benzo[g,h,i]perylene with the content of 1014.2 $\mu \mathrm{g} / \mathrm{kg}$ DM. Out of the tested 16 PAHs, the lowest mean concentration in STRB sewage sludge was determined for dibenzo[a,h]anthracene, which amounted to $37.3 \mu \mathrm{g} / \mathrm{kg} \mathrm{DM}$.

The general trend of changes in the sum of $16 \mathrm{PAHs}$ in sludge subjected to stabilization and dehydration in STRB in 2012-2014 was similar. The sludge layers from the shallowest to a depth of 1.5-2.0 m showed asteady increase in the sum of 16 PAHs. Then, in the two deepest layers located at the depths between $2.0 \mathrm{~m}$ and $3.0 \mathrm{~m}$, a decrease in 16 PAHs sum was observed.

The studies revealed that all sludge samples contained 11 PAHs sum according to WD [2000] and 16 PAHs sum according to EPA above $6 \mathrm{mg} / \mathrm{kg}$ DM.

Figure 2 presents the changes in PAHs contents divided into 3,4,5,6-ring ones. During the sludge stabilization and dehydration process in STRB, the highest concentration was recorded for 4-ring PAHs, which ranged from $2421.0 \mu \mathrm{g} / \mathrm{kg}$ DM to $3104.7 \mu \mathrm{g} / \mathrm{kg} \mathrm{DM}$. The highest content was observed for 3-ring PAHs group, which amounted from $1268.0 \mu \mathrm{g} / \mathrm{kg}$ DM to $1785.7 \mu \mathrm{g} / \mathrm{kg}$ DM.

The sum of 16 PAHs in the lowest sludge layer (2.5-3.0 m depth) was always lower than 16 PAHs sum for sludge from $0.0-0.5 \mathrm{~m}$ depth. The highest difference was recorded in 2012, when the sum of 16 PAHs in the oldest sludge layer was lower by $22.1 \%$ than the sum of 16 PAHs in the youngest (shallowest) layer of the sludge.

The research on the changes in the content of PAHs in sewage sludge stabilized and transformed in various ways by different researchers suggests the possibility of different behavior of these compounds during the process. A very high degree of 16 PAHs degradation sum, ranging from $89.8 \%$ to $98.9 \%$, was obtained during the fermentation of sewage sludge in an autoclave for 60 days, as reported by Chang et al. [2003]. Bernal-Martinez et al. reported that about 50\% decomposition of 16 PAHs sum occurred during fermentation of municipal sewage sludge [Bernal-Martinez 2005]. The use of anaerobic processes of biological decomposition of municipal sewage sludge has reduced the concentrations of PAHs from $45 \%$ to 55\% [Boruszko 2013b]. According to Oleszczuk et al., the sewage sludge compositing process with various proportions of structure-forming materials can cause a decrease 
2.1

2012

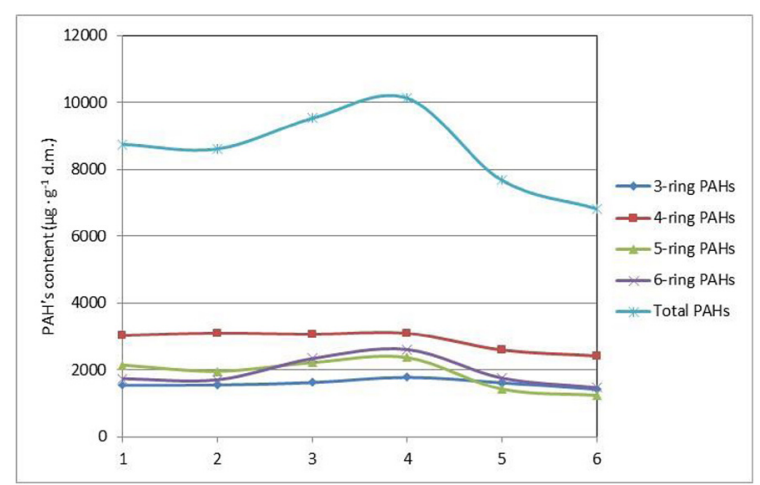

2.2

2013

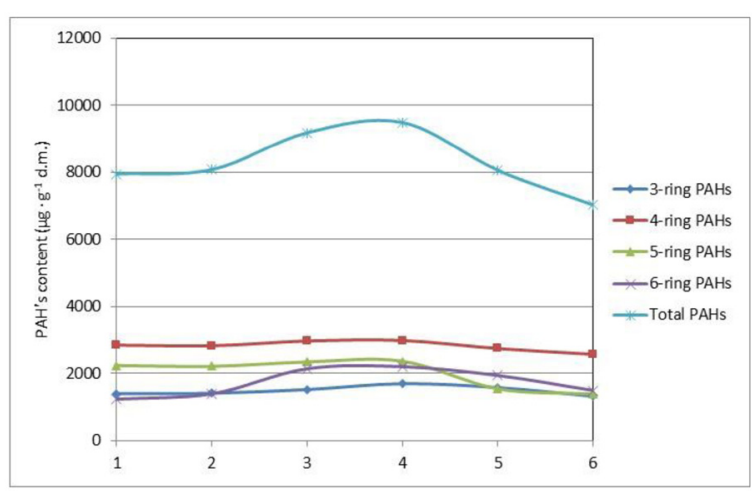

2.3

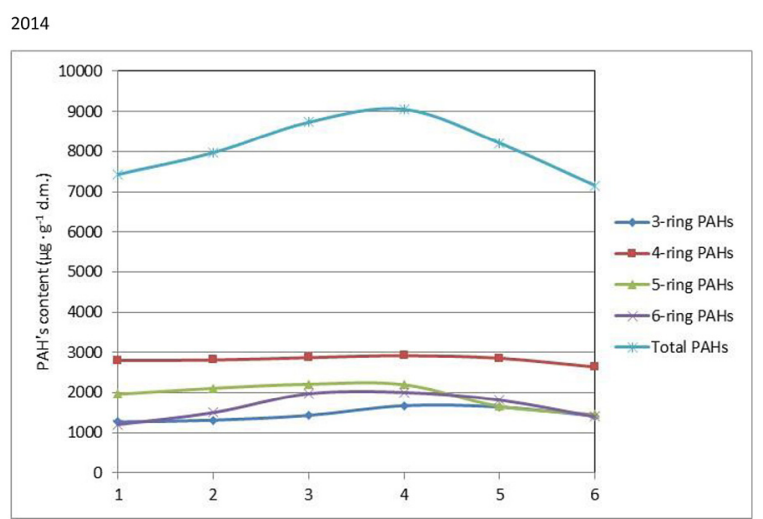

Figure 2. Changes of PAHs content in relations to number of rings in 2012, 2013 and 2014 year

in the sum content of 16 PAHs, even from $30 \%$ up to $70 \%$ [Oleszczuk 2004, 2009]. The authors also indicate the correlations between decomposition and degradation of individual PAHs as well as their sum vs. type and amount of available organic matter in the biomass [Oleszczuk 2006]. Other authors also report a high (about 50\%) degradation of 16 PAHs during composting of sewage sludge [Li et al. 2008; Amir et al., 2005; AntizarLadislao et al. 2004].

Different results were achieved by Villar, who found that composting and sludge stabilization process increased the content of PAHs sum [Villar 2006]. Decomposition of hydrocarbons can be performed both by pure bacterial strains and mixed populations, for which the intermediate products are a substrate for other ones. Besides bacteria, bio-degradation can be carried out by fungi, actinomycetes, some cyanobacteria and algae [Kanaly et al. 2000; Kastner et al. 1999]. Due to the action mechanism, microorganisms can be divided into two groups: ones that use hydrocarbons as the only source of carbon and energy (e.g. bacteria: Pseudomonas, Micrococcus, Alcaligens, and fungi: Candida, Fusarium, Aspergil- $l u s$ ) and the ones that have the ability to carry out co-metabolic transformations [Perez et al. 2001].

Table 2 presents the average concentrations of selected heavy metals in the sludge stabilized in reed bed system. Th eaverage sum of heavy metals in the sludge ranged from $1607.2 \mathrm{mg} / \mathrm{kg}$ DM in 2014 to $1635.2 \mathrm{mg} / \mathrm{kg} \mathrm{DM}$ in 2012. The highest content, among all analyzed heavy metals, was recorded for zinc with its mean concentration of $1301.1 \mathrm{mg} / \mathrm{kg} \mathrm{DM}$. Zinc is considered the most essential microelement for plant growth and its very high concentration (above 2500 $\mathrm{mg} / \mathrm{kg} \mathrm{DM}$ ) becomes toxic [Pathak et al. 2009]. The lowest content among all tested heavy metals was showed by mercury, at average content of $1.3 \mathrm{mg} / \mathrm{kg} \mathrm{DM}$. The analysis of heavy metal contents in particular layers (depths) of sewage sludge reveals an increase in zinc and copper levels, along with their processing time in the reed lagoon. The highest contents of these metals were recorded at the depth of 1.5-2.0 m (layer IV), which amounted to $1412.3 \mathrm{mg} \mathrm{Zn} / \mathrm{kg}$ $\mathrm{DM}$ and $247.0 \mathrm{mg} \mathrm{Cu} / \mathrm{kg} \mathrm{DM}$. The opposite trend was observed in the case of lead and chromium, the overall content of which decreased with the 
Table 2. The average concentrations of heavy metals in sludge stabilized in reed bed system (mg/kg d.m.)

\begin{tabular}{|c|c|c|c|c|c|c|c|}
\hline Year & 1 & II & III & IV & $\mathrm{V}$ & $\mathrm{VI}$ & Average \\
\hline \multicolumn{8}{|c|}{$\mathrm{Pb}$} \\
\hline 2012 & $38.5 \pm 0.9$ & $35.6 \pm 0.8$ & $31.3 \pm 0.6$ & $27.8 \pm 0.5$ & $27.1 \pm 0.4$ & $25.2 \pm 0.5$ & $30.9 \pm 5.2$ \\
\hline 2013 & $35.1 \pm 0.9$ & $34.7 \pm 0.9$ & $32.5 \pm 0.7$ & $26.8 \pm 0.6$ & $26.2 \pm 0.4$ & $24.2 \pm 0.8$ & $29.9 \pm 4.7$ \\
\hline 2014 & $33.8 \pm 0.7$ & $34.2 \pm 0.4$ & $33.2 \pm 0.6$ & $27.2 \pm 0.6$ & $25.8 \pm 0.6$ & $24.1 \pm 0.4$ & $29.7 \pm 4.5$ \\
\hline \multicolumn{8}{|c|}{$\mathrm{Cd}$} \\
\hline 2012 & $3.5 \pm 0.1$ & $3.4 \pm 0.1$ & $3.3 \pm 0.1$ & $3.2 \pm 0.1$ & $3.1 \pm 0.0$ & $2.6 \pm 0.1$ & $3.2 \pm 0.3$ \\
\hline 2013 & $3.2 \pm 0.1$ & $3.2 \pm 0.0$ & $3.0 \pm 0.0$ & $3.0 \pm 0.0$ & $3.0 \pm 0.0$ & $2.5 \pm 0.1$ & $3.0 \pm 0.2$ \\
\hline 2014 & $3.1 \pm 0.0$ & $3.1 \pm 0.0$ & $2.9 \pm 0.1$ & $2.5 \pm 0.1$ & $2.4 \pm 0.0$ & $2.4 \pm 0.0$ & $2.7 \pm 0.3$ \\
\hline \multicolumn{8}{|c|}{$\mathrm{Cr}$} \\
\hline 2012 & $75.4 \pm 0.7$ & $61.2 \pm 0.7$ & $54.3 \pm 0.6$ & $45.0 \pm 0.6$ & $42.3 \pm 0.7$ & $41.7 \pm 0.8$ & $53.3 \pm 13.2$ \\
\hline 2013 & $71.1 \pm 0.6$ & $62.2 \pm 0.9$ & $53.2 \pm 0.5$ & $46.0 \pm 0.6$ & $43.0 \pm 0.6$ & $42.4 \pm 0.5$ & $53.0 \pm 11.6$ \\
\hline 2014 & $70.1 \pm 0.5$ & $64.3 \pm 0.6$ & $55.1 \pm 0.6$ & $48.3 \pm 0.4$ & $44.1 \pm 0.4$ & $41.2 \pm 0.5$ & $53.9 \pm 11.5$ \\
\hline \multicolumn{8}{|c|}{$\mathrm{Cu}$} \\
\hline 2012 & $156.3 \pm 3.1$ & $183.0 \pm 3.0$ & $223.7 \pm 4.2$ & $247.0 \pm 6.6$ & $236.7 \pm 2.5$ & $224.3 \pm 3.5$ & $211.8 \pm 34.8$ \\
\hline 2013 & $143.3 \pm 5.5$ & $173.3 \pm 2.5$ & $211.0 \pm 5.6$ & $232.0 \pm 7.0$ & $243.7 \pm 6.0$ & $243.7 \pm 5.5$ & $207.8 \pm 41.3$ \\
\hline 2014 & $154.0 \pm 5.6$ & $178.3 \pm 1.5$ & $223.3 \pm 5.5$ & $211.7 \pm 63.0$ & $251.3 \pm 6.5$ & $254.3 \pm 5.0$ & $212.2 \pm 39.9$ \\
\hline \multicolumn{8}{|c|}{$\mathrm{Ni}$} \\
\hline 2012 & $18.2 \pm 0.3$ & $19.0 \pm 0.4$ & $19.5 \pm 0.4$ & $18.9 \pm 0.3$ & $19.1 \pm 0.3$ & $18.5 \pm 0.3$ & $18.9 \pm 0.5$ \\
\hline 2013 & $19.6 \pm 0.7$ & $19.8 \pm 0.7$ & $19.1 \pm 0.4$ & $19.8 \pm 0.6$ & $19.5 \pm 0.5$ & $19.5 \pm 0.4$ & $19.6 \pm 0.3$ \\
\hline 2014 & $18.2 \pm 0.6$ & $19.2 \pm 0.2$ & $19.5 \pm 0.3$ & $19.3 \pm 0.4$ & $20.2 \pm 0.3$ & $20.0 \pm 0.5$ & $19.4 \pm 0.7$ \\
\hline \multicolumn{8}{|c|}{$\mathrm{Zn}$} \\
\hline 2012 & $1224.3 \pm 14.0$ & $1316.0 \pm 14.5$ & $1355.7 \pm 19.6$ & $1399.0 \pm 12.5$ & $1374.0 \pm 9.0$ & $1225.3 \pm 14.2$ & $1315.7 \pm 75.4$ \\
\hline 2013 & $1184.7 \pm 7.0$ & $1276.0 \pm 11.0$ & $1324.3 \pm 14.6$ & $1412.3 \pm 10.5$ & $1398.0 \pm 8.0$ & $1244.3 \pm 5.0$ & $1306.6 \pm 88.9$ \\
\hline 2014 & $1206.0 \pm 7.5$ & $1254.7 \pm 9.1$ & $1312.0 \pm 9.0$ & $1396.3 \pm 7.0$ & $1346.7 \pm 8.6$ & $1213.3 \pm 10.6$ & $1288.2 \pm 76.4$ \\
\hline \multicolumn{8}{|c|}{$\mathrm{Hg}$} \\
\hline 2012 & $1.5 \pm 0.1$ & $1.5 \pm 0.1$ & $1.3 \pm 0.1$ & $1.3 \pm 0.1$ & $1.3 \pm 0.1$ & $1.2 \pm 0.1$ & $1.4 \pm 0.1$ \\
\hline 2013 & $1.0 \pm 0.0$ & $1.3 \pm 0.0$ & $1.4 \pm 0.0$ & $1.2 \pm 0.1$ & $1.2 \pm 0.1$ & $1.3 \pm 0.0$ & $1.2 \pm 0.1$ \\
\hline 2014 & $1.1 \pm 0.0$ & $1.2 \pm 0.0$ & $1.2 \pm 0.0$ & $1.2 \pm 0.0$ & $1.2 \pm 0.0$ & $1.2 \pm 0.0$ & $1.2 \pm 0.1$ \\
\hline \multicolumn{8}{|c|}{ Total } \\
\hline 2012 & $1517.8 \pm 10.8$ & $1619.8 \pm 10.9$ & $1689.1 \pm 23.9$ & $1742.3 \pm 5.6$ & $1703.5 \pm 7.0$ & $1538.8 \pm 10.7$ & $1635.2 \pm 92.0$ \\
\hline 2013 & $1458.0 \pm 11.9$ & $1570.5 \pm 7.9$ & $1644.6 \pm 9.8$ & $1741.1 \pm 18.0$ & $1734.7 \pm 13.3$ & $1577.9 \pm 12.2$ & $1621.1 \pm 108.5$ \\
\hline 2014 & $1486.2 \pm 13.7$ & $1555.0 \pm 9.3$ & $1647.2 \pm 14.2$ & $1706.5 \pm 56.6$ & $1691.7 \pm 15.9$ & $1556.6 \pm 7.1$ & $1607.2 \pm 87.8$ \\
\hline
\end{tabular}

\pm - standard deviation

(I - depth 0.0-0.5 m, II - depth 0.5-1.0 m, III - depth 1.0-1.5 m, IV - depth 1.5-2.0 m, V - depth 2.0-2.5 m, VI - depth 2.5-3.0 m)

sludge layer depth in the reed lagoon. The highest average loss of the total content was observed in relation to chromium, the concentration of which fell by $26.4 \%$.

Figure 3 presents the average concentrations of selected heavy metals and their speciation in the sludge stabilized in a reed bed system. All the analyzed heavy metals were related mainly to the most stable connections (fraction IV). The highest share of fraction IV in the total content was observed in the case of lead, which was on average $91.4 \%$, and chromium $-90.3 \%$. The lowest participation of fraction IV in relation to the total content was observed for zinc, and it amounted to an average of $48.2 \%$. The highest share in the most mobile fraction I was observed in the case of nickel, which amounted to an average of $10.9 \%$. With regard to lead, cadmium and chromium, there was no presence of these metals compounds in fractions I and II, while their share in the fraction IV was high. Therefore, they are metals present in the most stable form. Moreover, other authors showed that in the sewage sludge stabilized by means of conventional methods, lead was the most bound, and the most abundant in the fraction IV [Alvarez et al. 2002; Scancar et al. 2000].

In fraction III (organic), the highest share was revealed by copper from $24.4 \%$ to $24.6 \%$, zinc from $23.4 \%$ to $23.8 \%$, as well as nickel from $21.4 \%$ to $22.9 \%$. The analyzed sludge types showed the largest share in mobile fractions (I, II, III) by zinc from $50.8 \%$ to $51.8 \%$ and nickel 
3.1

2012

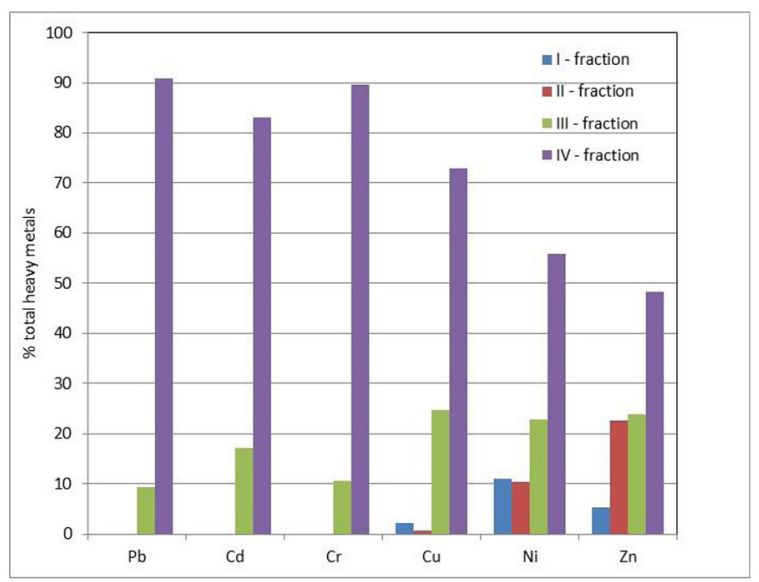

3.2

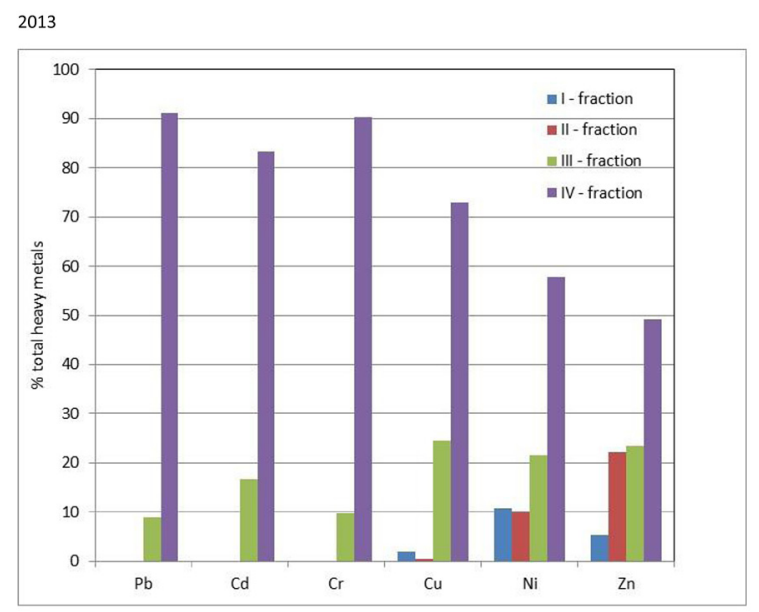

3.3

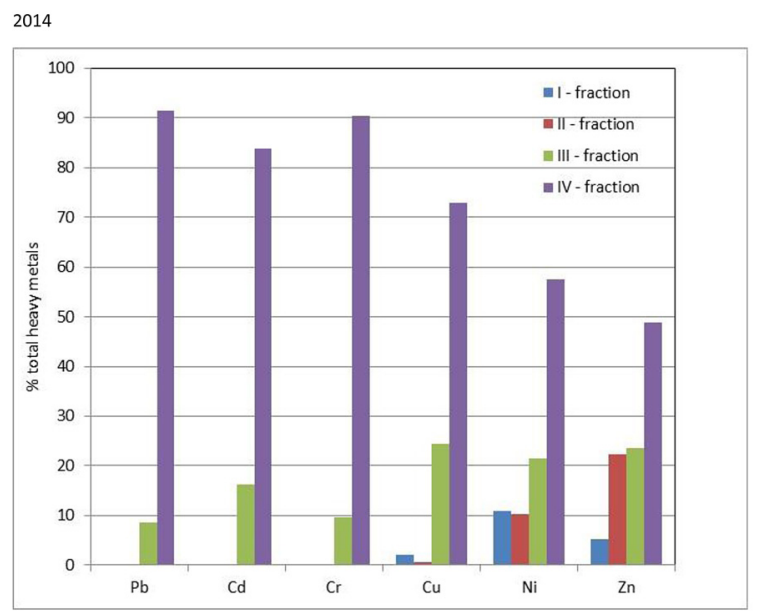

Figure 3. The average concetrations of heavy metals, their speciacion in sludge stabilized in reed bed system in 2012, 2013 and 2014 year

from $42.2 \%$ to $44.2 \%$. In addition, the literature data indicate that zinc and nickel are present at largest quantities in mobile fractions (I, II, III) of stabilized sludge [Fuentes et al. 2008; Alvarez et al. 2002; Scancar et al. 2000].

The study on the changes in the physicochemical properties of sludge dehydrated and stabilized in reed lagoons showed significant differences with respect to the working phase - closing of the lagoon and to the work time of the object (vertical profile).

Spearman's rank correlation coefficient was used to study the relationship between the quantitative parameters and to describe the strength of the correlation. Table 3 shows the results of statistical calculations of Spearman's rank correlation order for a series of tests during the conducted experiment. The determined PAHs contents in sludge types during the experiment were grouped dividing into the number of rings. All studied pa- rameters (PAHs, heavy metals) were grouped in pairs with respect to the depth (sludge layers).

The correlation coefficients are significant at $p<0.05$. The rank correlation coefficient takes values from the interval $[-1 ; 1]$. The same rank values of tested variables testify to the existence of a positive correlation between them $(\mathrm{X}=\mathrm{Y}=1)$, i.e. $\mathrm{Y}$ increases always altogether with $\mathrm{X}$ and vice versa. The opposite numbering suggests a negative correlation (when one parameter increases, the second decreases). A positive sign of the coefficient indicates the existence of a positive correlation (increase of one parameter causes an increase in the other). The closer the correlation coefficient is to unity, the stronger the correlative relationship. The calculations reveal that the strongest positive correlation $(\mathrm{RS}=0.9750)$ characterizes the total phosphorus content in sludge with respect to the sludge layer (i.e. duration of its stabilization in STRB). Slightly lower posi- 
Table 3. Correlation of order of Spearman ranks, indicated coefficients of correlation are essential $p<0.05000$

\begin{tabular}{|c|c|c|c|c|c|c|c|c|c|c|c|c|c|c|c|c|c|c|}
\hline & epth & $\begin{array}{l}\text { 3-ring } \\
\text { PAHs } \\
\end{array}$ & $\begin{array}{l}\text { 4-ring } \\
\text { PAHs } \\
\end{array}$ & \begin{tabular}{l|}
$\mathrm{Aing}$ \\
$\mathrm{AHs}$
\end{tabular} & $\begin{array}{l}\text { 6-ring } \\
\mathrm{PAHs} \\
\end{array}$ & $\begin{array}{c}\text { Tot } \\
\text { PAHs } \\
\end{array}$ & $\mathrm{Pb}$ & Cd & $\mathrm{Cr}$ & $\mathrm{Cu}$ & $\mathrm{Ni}$ & $\mathrm{Zn}$ & $\mathrm{Hg}$ & $M_{\text {tot }}$ & DM & OM & $\mathrm{N}_{\mathrm{k}}$ & $P_{\text {tot }}$ \\
\hline epth & 00 & 853 & 1922 & 36 & 5 & 2916 & 2 & .7057 & 3 & 8971 & 3262 & 29 & 00 & 33 & 1 & 9562 & .8621 & 9750 \\
\hline $\begin{array}{l}\text { ring } \\
\mathrm{AHs}\end{array}$ & 3 & 000 & 5583 & 3457 & .8349 & 0.7110 & 2198 & 77 & 6 & 29 & 6 & 6 & 1146 & 3 & 43 & 2260 & 64 & .3519 \\
\hline $\begin{array}{l}- \text {-ring } \\
\mathrm{AHS} \\
\end{array}$ & 4922 & 5583 & 0000 & 7668 & 6037 & 9009 & 529 & 5369 & 1757 & -0.2148 & -0.13 & 3953 & 6 & 251 & -0.7337 & 61 & 0.7090 & 0.3849 \\
\hline $\begin{array}{l}\text { 5-ring } \\
\text { PAHs }\end{array}$ & 5236 & 0.3457 & 7668 & 1.0000 & 0.5191 & 0.8225 & 4819 & 4223 & 5046 & -0.3098 & 0465 & 3271 & 1642 & 2652 & -0.7668 & 4613 & 6594 & 0.4840 \\
\hline \begin{tabular}{l|}
$6-$ ring \\
PAHs \\
\end{tabular} & 975 & 3349 & 3037 & 191 & 0000 & 8328 & 1496 & 0330 & 0 & 0 & 6 & 4 & 2 & 9 & 51 & 35 & 8 & 34 \\
\hline \begin{tabular}{c|} 
Tot \\
PAHs \\
\end{tabular} & 2916 & 7110 & 9009 & 0.8225 & 0.8328 & 1.0000 & 3127 & 3655 & 2859 & -0.0299 & -0.0186 & 6491 & 0.3779 & 0.5851 & -0.7214 & 2755 & 0.5253 & 0.2157 \\
\hline $\mathrm{Pb}$ & 562 & 2198 & 294 & 819 & 1496 & 3127 & & & & 3 & & & & 32 & 4 & & 66 & 298 \\
\hline $\mathrm{Cd}$ & 057 & 237 & 369 & 223 & 330 & 655 & & & & & & & & 00 & 6 & & & 18 \\
\hline $\mathrm{Cr}$ & & - & 4757 & 5046 & & 2859 & & & & & & & & & & & & \\
\hline $\mathrm{Cu}$ & 971 & 29 & 1 & 98 & 0.3934 & 9 & & & & 1.0000 & & & & & 5 & 3 & & \\
\hline $\mathrm{Ni}$ & 262 & 1156 & 1332 & 0.0465 & 0186 & .0186 & -0.3913 & 81 & 2747 & 0.4003 & 00 & 31 & -0.2882 & 0.2488 & 0.2850 & 3645 & 31 & 3366 \\
\hline $\mathrm{Zn}$ & -1 & 576 & 53 & 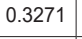 & 0.8514 & 491 & -0.2611 & D.0196 & -0.3437 & 0.4739 & & 0 & 0 & 0 & & 5 & 2 & 0.3168 \\
\hline $\mathrm{Hc}$ & -0.1600 & 0.1146 & 0.4316 & 0.1642 & 0.2912 & 0.3779 & & & & 4 & & & & & & 3273 & & \\
\hline $\mathrm{HM}_{\mathrm{tot}}$ & 33 & 493 & 51 & 52 & 9 & 351 & 2 & 00 & 34 & 0.6205 & 88 & 0 & 34 & 1.0000 & 6 & 30 & 54 & 0.4448 \\
\hline DM & 361 & 4943 & 7337 & -0.7668 & 4551 & -0.7214 & & & & & & & & & & 12 & & 54 \\
\hline $\mathrm{OM}$ & -0.9562 & 260 & 861 & 0.4613 & 1785 & 755 & 0.9773 & 0.8240 & 0.9174 & 73 & 5 & 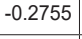 & 3 & 0 & 2 & 0 & 4 & 0 \\
\hline$N_{k}$ & -0.8621 & 0.0464 & 0.7090 & 0 & 0.0898 & 0.5253 & 0.8906 & 0.8952 & 0.8142 & -0 & 1 & 2 & 4 & 4 & 3 & 74 & 0 & \\
\hline$P_{\text {tot }}$ & 0. & 19 & 49 & 0 & 4 & 7 & -0.9298 & 8 & 7 & 7 & 6 & & 33 & 8 & 44 & 36 & 36 & 0 \\
\hline
\end{tabular}

tive correlation $(\mathrm{RS}=0.9009)$ was achieved for 4-ring PAHs in relation to the sum of 16 PAHs. High positive Spearman correlation coefficient (RS > 0.9) was also recorded for the total lead and chromium contents in relation to the organic matter. The strongest negative Spearman correlation ( RS > 0.9) with respect to the sludge layer depth was observed for organic matter and total contents of lead and chromium.

Another statistical analysis of the achieved results was based on the use of two ANOVA tests: Kruskal-Wallis's and Friedman's. The KruskalWallis ANOVA allowed to analyze the data as independent from each other (not related in pairs), while the Friedman's test allows to analyze data as dependent on one another (linked in pairs). The analyses were performed in two variants: comparing the data from three years $(2012,2013$, 2014), (Table 4), and comparing the data according to 6 depths (Table 5). The red color highlights the statistically significant K-W test results, i.e. $\mathrm{p}<0.05$. In addition, only for those results, the median test results are presented. It allows to precisely recognize which data groups are similar or different. The test results close to zero indicate the data pairs with strong statistical dependencies.

The results of statistical tests show a strong affinity for most of the tested parameters in the sewage sludge stabilized in STRB to the depth (sludge layer), and thus indirectly to the time of their dehydration and stabilization (Table 5), both as dependent and independent from each other. However, in relation to the three years of study (2012-2014), such affinity was not found

Table 4. Results of the statistic tests - year rank

\begin{tabular}{|c|c|c|c|c|c|c|c|c|c|c|c|c|c|c|c|c|c|}
\hline Statistic test & $\begin{array}{l}\text { 3-ring } \\
\text { PAHs }\end{array}$ & $\begin{array}{l}\text { 4-ring } \\
\text { PAHs }\end{array}$ & $\begin{array}{l}\text { 5-ring } \\
\text { PAHs }\end{array}$ & $\begin{array}{l}\text { 6-ring } \\
\text { PAHs }\end{array}$ & Tot PAHs & $\mathrm{Pb}$ & $\mathrm{Cd}$ & $\mathrm{Cr}$ & $\mathrm{Cu}$ & $\mathrm{Ni}$ & $\mathrm{Zn}$ & $\mathrm{Hg}$ & $\mathrm{HM}_{\mathrm{tot}}$ & DM & OM & $N_{k}$ & $P_{\text {tot }}$ \\
\hline Friedman & 0.0421 & 0.5134 & 0.3114 & 0.1146 & 0.5134 & 0.1146 & 0.0025 & 0.5134 & 0.3114 & 0.3114 & 0.0421 & 0.1146 & 0.2231 & 0.0025 & 0.0025 & 0.0025 & 0.5134 \\
\hline $\begin{array}{l}\text { Kruskal- } \\
\text { Wallis }\end{array}$ & 0.3235 & 0.4758 & 0.63 & 0.63 & 0.7165 & 0.7961 & 0.0388 & 0.9599 & 0.9322 & 0.057 & 0.6918 & 0.0621 & 0.8948 & 0.3993 & 0.6227 & 0.2026 & 0.9599 \\
\hline
\end{tabular}

Table 5. Results of the statistic tests - depth rank

\begin{tabular}{|c|c|c|c|c|c|c|c|c|c|c|c|c|c|c|c|c|c|}
\hline $\begin{array}{c}\text { Statistic } \\
\text { test }\end{array}$ & \begin{tabular}{|l|} 
3-ring \\
PAHs
\end{tabular} & \begin{tabular}{|l|} 
4-ring \\
PAHs
\end{tabular} & \begin{tabular}{|l|} 
5-ring \\
PAHs
\end{tabular} & \begin{tabular}{|l|} 
6-ring \\
PAHs
\end{tabular} & \begin{tabular}{|c|} 
Tot \\
PAHs \\
\end{tabular} & $\mathrm{Pb}$ & $\mathrm{Cd}$ & $\mathrm{Cr}$ & $\mathrm{Cu}$ & $\mathrm{Ni}$ & $\mathrm{Zn}$ & $\mathrm{Hg}$ & $\mathrm{HM}_{\text {tot }}$ & DM & OM & $\mathrm{N}_{\mathrm{k}}$ & $P_{\text {tot }}$ \\
\hline Friedman & 0.0193 & 0.0412 & 0.0142 & 0.0193 & 0.0193 & 0.0121 & 0.0236 & 0.0104 & 0.0254 & 0.6126 & 0.0104 & 0.1938 & 0.0121 & 0.0121 & 0.0121 & 0.0104 & 0.0104 \\
\hline $\begin{array}{l}\text { Kruskal- } \\
\text { Wallis }\end{array}$ & 0.0254 & 0.0521 & 0.0153 & 0.0129 & 0.0162 & 0.0071 & 0.1089 & 0.0058 & 0.0131 & 0.7418 & 0.0075 & 0.3908 & 0.0069 & 0.0106 & 0.0073 & 0.0223 & 0.0062 \\
\hline ledian & 0.0752 & 0.0752 & 0.0267 & 0.0029 & 0.0752 & 0.0029 & 0.0752 & 0.0029 & 0.0267 & 0.8491 & 0.0267 & 0.4579 & 0.0029 & 0.0267 & 0.0029 & 0.0267 & 0.0029 \\
\hline
\end{tabular}


for most of the tested parameters. The results of these tests can suggest that the closure of the reed lagoon (end of the sludge supply), for a short time (one year before and one after the closure) had a significant effect only on the content of nitrogen as well as dry matter and organic matter in the deposited sludge.

\section{CONCLUSIONS}

Summing up the results and study results obtained from the long-term stabilization and dehydration of sewage sludge in the reed lagoon, the following conclusions can be drawn:

1. An increase in dry matter and decline of organic matter occurred in the stabilized sewage sludge.

2. The phosphorus concentration in sewage sludge increased along with the depth of the sludge layer. In contrast, the concentration of total nitrogen decreased with increasing sludge layer depth.

3. The concentrations of nitrogen and phosphorus in dry matter were relatively high.

4. The concentration of 16 PAHs sum was very high, which prevents the use of sludge in agriculture.

5. Long-term stabilization of sewage sludge in STRB reduces the sum of 16 PAHs, although their increase was observed in the first few years.

6. The total concentration of heavy metals allows the agricultural use of sewage sludge.

7. Heavy metals were usually bound to the residual fraction, which is the most stable.

8. The statistical analysis showed very strong correlations with the depth of the sludge layer.

\section{Acknowledgments}

The study was conducted as a research project S/WBiIŚ/3/2014 in Faculty of Building and Environmental Engineering of BUT and financed by Ministry of Science and Higher Education.

\section{REFERENCES}

1. Alvarez E.A., Mochon M.C., Sanchez J.C.J. \& Rodriguez M.T., 2002 Heavy metal extractable forms in sludge from wastewater treatment plants. Chemosphere, 47, 765-775.
2. Amir S., Hafidi M., Merlina G., Hamdi H., Revel J.C. 2005 Fate of polycyclic aromatic hydrocarbons during composting of lagooning sewage sludge. Chemosphere, 58, 449-458.

3. Antizar-Ladislao B., Lopez-Real J.M., Beck A.J. 2004 Bioremediation of polycyclic aromatic hydrocarbons - contaminated waste using composting approaches. Critical Reviews in Environmental Science and Technology, 34, 249-289.

4. Aparicio I., Santos J.L., Alonso E., 2009 Limitation of the concetration of organic pollutants in sewage sludge for agricultural purposes: A case study in South Spain, Waste Management, 29, 217-228.

5. Bernal-Martinez A., Carrere H., Patureau D., Delgenes J.P. 2005 Combining anaerobic digestion and ozonation to remove PAH from urban sludge. Process Biochemistry, 40, 3244-3250.

6. Boruszko D. 2013a Fractionation of Heavy Metals in Sewage Sludge processed by Low-input methods. Annual Set The Environment Protection, 15 (2), 1787-1803.

7. Boruszko D. 2013b Impact low-cost processing methods on the contents of polycyclic aromatic hydrocarbons (PAHSs) in sewage sludge. Ecological Chemistry and Engineering, 20 (10), 1153-1161.

8. Boruszko D., Butarewicz A. 2015 Impact of effective microorganisms bacteria on low-input sewage sludge treatment. Environment Protection Engineering, 41 (4), 83-96.

9. Chang B.V., Chang S.W., Yuan S.Y. 2003 Anaerobic degradation of polycyclic aromatic hydrocarbon in sludge. Advances in Environmental Research, 7, 623-628.

10. Fuentes A., Llorens M., Saez J., Aguilar M.I., Ortuno J. \& Meseguer V.F. 2008 Comparative study of six different sludges by sequential speciation of heavy metals. Bioresourse Technology, 99 (3), 517-525.

11. Gomez Palacios J.M., Ruiz de Apodaca A., Rebollo C., Azcarate J. 2002 European policy on biodegradable waste: a management perspective. Water Science Technology, 46, 311-318.

12. Kanaly R.A., Harayama S. 2000 Biodegradation ofhigh molecular weidght polycyclic aromatic hydrocarbons by bacteria. Journal of Bacteriology, 182, 2059-2069.

13. Kapanen A., Vikman M., Rajasarkka J., Virta M., Itavaara M. 2013, Biotest for environmental quality assessment of composed sewage sludge. Waste Management, 33, 1451-1460.

14. Kastner M., Streibich S., Beyer M., Richnow H.H., Fritsche W. 1999 Formation of bount residues during microbial degradation of $[14 \mathrm{C}]$ anthracene in soil. Applied and Environmental Microbiology, 65, 1834-1842. 
15. Kazi T.G., Jamali M.K., Kazi G.H., Arian M.B., Afridi H.I. \& Siddiqui A. 2005 Evaluating the mobility of toxic metals in untreated industriak wastewater sludge using a BCR sequential extraction procedurę and a leaching test. Analytical and Bioanalytical Chemistry, 383, 297-304.

16. Kołecka K. \& Obarska-Pempkowiak H. 2008 The quality of sewage sludge stabilized for a long time in reed baśni. Environment Protection Engineering, 34 (3), 13-20.

17. Langenkamp H., Part P. 2001 Organic contaminants in sewage sludge for agricultur use, European Commision Joint Research Centre Institute for Environment and Sustainability Soil and Waste Unit.

18. Li H., Wu W., Liu Y., Chen Y., Murray B. 2008, Effect of Composting on Polycyclic Aromatic Hydrocarbons Removal in Sewage Sludge. Water, Air Soil Pollution, 193, 259-267.

19. Matamoros V., Nguyen L. X., Arias C.A., Nielsen S., Laugen M.M. \& Brix H. 2012 Musk fragrances, DEHP and heavy metals in a 20 year old sludge treatment reed bed system. Water Research, 46 (12), 3889-3896.

20. Nielsen S., 2005 Sludge reed bed facilitis: operation and problems. Water Science and Technology, $51(9), 99-107$.

21. Nielsen S., 2011 Sludge treatment reed bed facilities - organic load and operation problems. Water Science and Technology, 63 (5), 941-947.

22. Nielsen S., Peruzzi E., Macci C., Doni S. \& Masciandaro G. 2012 Stabilisation and mineralization of sludge in reed bed system after 10-20 years of operation. 13th International IWA Specialist Group Conference on Wetland Systems for Water Pollution Control 25-30 November 2012. Perth, Australia.

23. Oleszczuk P., Baran S. 2004 The concentration of mild-extracted polycyclic aromatic hydrocarbons in sewage sludges. Journal of Environmental Science and Health, 11, 2799-2815.

24. Oleszczuk P. 2006 Influence of different bulking agents on the disapparance of PAHs during sewage sludge composting. Water, Air and Soil Pollution, $175,15-32$.

25. Oleszczuk P. 2009 Application of three methods used for the evaluation of policyclic aromatic hydrocarbons (PAHs) bioacessibility for dewage sludge composting. Bioresource Technology, 100, 413-420.

26. Pathak A., Dastidar M.G. \& Sreekrishnan T.R. 2009 Bioleaching of heavy metals from sewage sludge: a review. Journal of Environmental Management, 90 (8), 2343-2353.
27. Pérez S, La Farré M, García JM, Barceló D. 2001 Occurrence of polycyclic aromatic hydrocarbons in sewage sludge and their contribution to its toxicity in the ToxAlert ${ }^{\circledR} 100$ bioassay. Chemosphere, 45 (6-7), 705-712.

28. Peruzzi E., Macci C., Doni S., Masciandaro G., Peruzzi P., Aiello M. \& Ceccanti B. 2009 Phragmites australis for sewage sludge stabilization. Desalination, 246, 110-119.

29. Peruzzi E., Masciandaro G., Macci C., Doni S., Mora Rayelo S.G., Peruzzi P \& Ceccanti B. 2011 heavy metal fractonation and organic mater stabilization in sewage sludge treatment wetlands. Ecological Engineering, 37 (5),771-778.

30. Scancar J., Milacic R. \& Burica O. 2000 Total metal concentrations and partotioning of $\mathrm{Cd}, \mathrm{Cr}, \mathrm{Cu}$, $\mathrm{Fe}, \mathrm{Ni}, \mathrm{Pb}$ and $\mathrm{Zn}$ in sewage sludge. The Science of the Total Environment, 250, 9-10.

31. Sidney S. 1956 Non-parametric statistics for the behavioral sciences. Nowy York, McGraw-Hill.

32. Smolik E. 2005 Polycyclic aromatic hydrocarbons (PAHs). Instytut Medycyny Pracy i Zdrowia Środowiskowego. [in Polish]

33. Standard Methods for the Examination of Water and Wastewater 2005 21th edn, American Public Health Association/American Water Works Association/Water Environment Federation, Washington DC, USA.

34. Sobczyk M. 2002 Statystyka, Wydawnictwo PWN. [in Polish]

35. Uggetti E., Ferrer I., Llorens E \& Garcia J. 2010 sludge treatment wetlands a review on the state of the art. Biresouce Technology, 101 (9), 2905-2912.

36. Vacha R., Vyslouzilova M., Horvathova V., Cechmankova J. 2006 Recommended maximum contents of persistent organic pollutants in sewage sludge for application on agricultural soils. Plant Soil Environment, 52 (8), 362-367.

37. Villar P., Callejon M., Alonso E., Jimenez J. C., Guiraum A. 2006 Temporal evolution of polycyclic aromatic hydrocarbons (PAHs) in sludge from wastewater treatment plants: Comparison between PAHs nad Heavy metals. Chemosphere, 64, 535-541.

38. Working Document on Sludge, and Biowaste, 2010 Council of the European Community, Brussels, Belgie.

39. Working Document on Sludge, 3rd Draft, 2000 Council of the European Community, Brussels, Belgie.

40. Zwara W. \& Obarska-Pempkowiak H. 2000 Polish experience with sewage sludge utilization in reed beds. Water Science and Technology, 41 (1), 65-68. 